\title{
Norwich paediatric triad: malrotation, intussusception and small intestinal lymphoma
}

\author{
C K Sinha, ${ }^{1}$ S Basson, ${ }^{1}$ R V Patel, ${ }^{2}$ A B Mathur ${ }^{1}$
}

'Department of Paediatric Surgery, NNUH, Norwich, UK ${ }^{2}$ Department of Paediatric Urology, University College London Hospitals NHS Foundation Trust, London, UK

\section{Correspondence to} CK Sinha,

cksinha@btinternet.com

Accepted 10 November 2014
CrossMark

To cite: Sinha $C \mathrm{~K}$, Basson S, Patel R V, et al. BMJ Case Rep Published online: [please include Day Month Year] doi:10.1136/ bcr-2013-201110

\section{DESCRIPTION}

A previously healthy 13 -year-old girl presented with abdominal pain for 2 days, initially in the periumbilical area and subsequently in the left upper quadrant. She had a few episodes of green vomiting, but had normal bowel movements. On examination, she was alert and haemodynamically stable. Her abdomen was tender in the left upper quadrant and had a soft mass. Laboratory investigations and chest radiograph were normal except for microcytic anaemia. Abdominal radiograph showed abnormal distribution of dilated bowel loops (figure 1A) and ultrasound scan revealed a target and pseudo kidney signs suggestive of an intussusception with a possible lead point on the left side of her abdomen and raised concerns of malrotation (figure 1B). Abdominal CT scan with contrast revealed intussusception, a lead point and associated midgut malrotation (figure 1C,
D). At laparotomy, a midgut malrotation with ileocolic intussusception and a fleshy mass as lead point were found with viable bowel. A limited right hemicolectomy using Ladd's procedure was performed uneventfully. Histopathology confirmed the lead point to be non-Hodgkin's lymphoma. The patient was started on an appropriate chemotherapy regime by the oncology team. A combination of malrotation and intussusception is called Waugh's syndrome. ${ }^{1}$ Triad of midgut malrotation, ileocolic intussusception and gut lymphoma has not been reported earlier in the literature in children and only one case has been reported in adults. ${ }^{2}$ We have named it 'Norwich triad'. Air enema reduction is difficult, and recurrence is inevitable due to lead point delaying the diagnosis and treatment. At exploration the lead point should be resected for detailed histopathological diagnosis. ${ }^{3}$
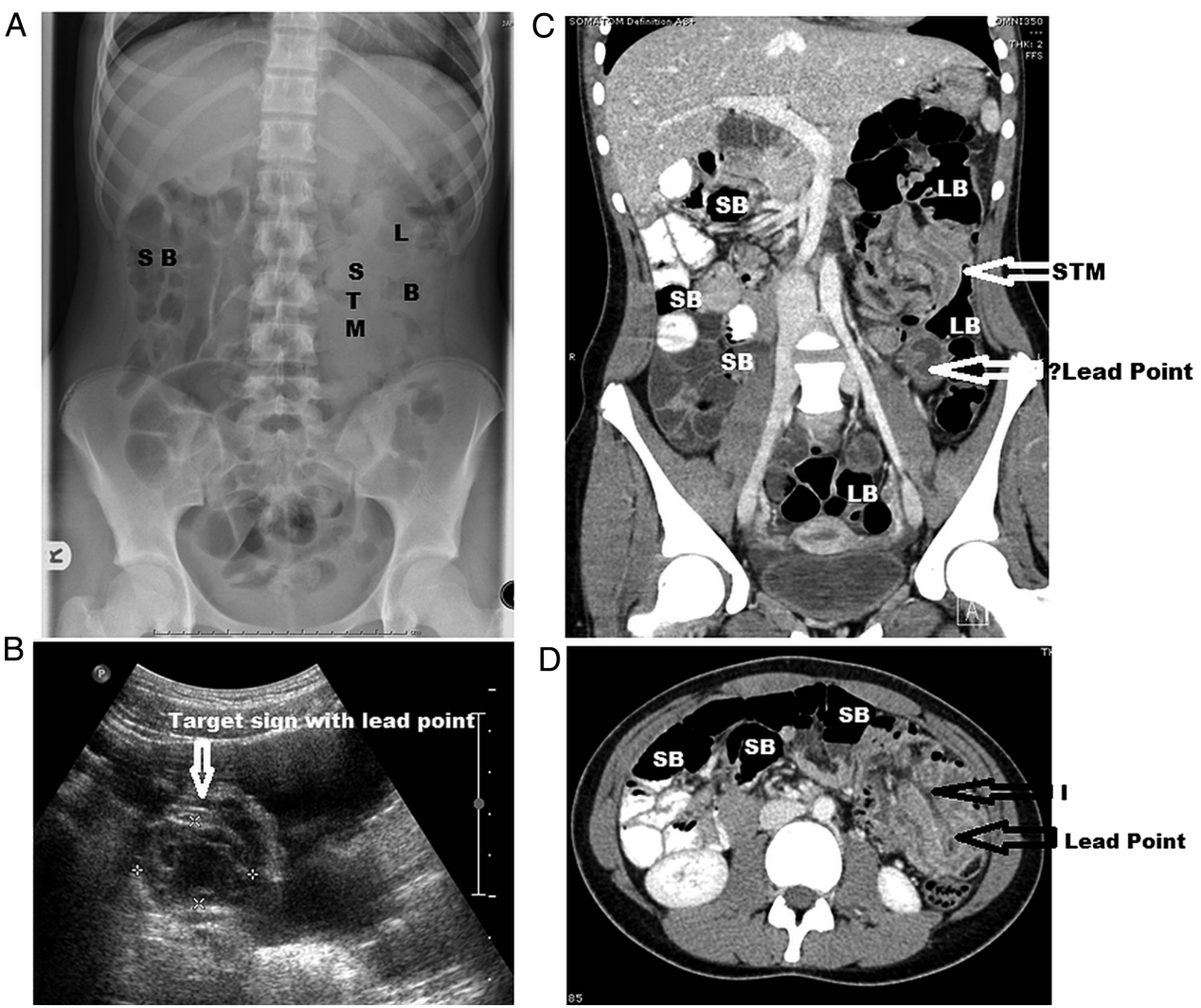

Figure 1 (A) Abdominal radiograph dilated small bowel (SB) gas pattern on the right side, a soft tissue mass (STM) in the left upper abdomen and normal large bowel (LB) gas on the left side. (B) The ultrasound scan showing target sign of intussusception (T-I) with a possible lead point (LP). (C and D) CT scan with contrast showing midgut malrotation with dilated SB loops on the right side, intussusception (I) in the left upper abdomen and a LP just below it. 


\section{Learning points}

- A triad of malrotation, intestinal lymphoma and intussusception (Norwich Triad) in a child has not been reported earlier.

- A palpable sausage-shaped mass on the left side of the abdomen clinically in association with abnormal small bowel gas shadows on the right side of the abdomen and large bowel on the left side on abdominal radiograph and an intussusception with a possible lead point should be a warning sign of the possibility of a Norwich triad.

- In adolescent intussusception, a lead point is more likely to be a lymphoma, hence surgical exploration saves time, shortens bowel ischaemia and provides histological diagnosis for prompt and appropriate chemotherapy to be instituted.
Competing interests None.

Patient consent Obtained.

Provenance and peer review Not commissioned; externally peer reviewed.

\section{REFERENCES}

1 Brereton RJ, Taylor B, Hall CM. Intussusception and malrotation in infants: Waugh's syndrome. Br J Surg 1986;73:55-7.

2 Breckon VM, Hadley GP. Waugh's syndrome: a report of six patients. Pediatr Surg Int 2000;16:370-3.

3 Baltazar G, Sahyoun C, Sime J, et al. Discovery of a case of Waugh's syndrome during a mission to Haiti. Int I Surg Case Rep 2012;3:22-4.

Copyright 2014 BMJ Publishing Group. All rights reserved. For permission to reuse any of this content visit

http://group.bmj.com/group/rights-licensing/permissions.

BMJ Case Report Fellows may re-use this article for personal use and teaching without any further permission.

Become a Fellow of BMJ Case Reports today and you can:

- Submit as many cases as you like

- Enjoy fast sympathetic peer review and rapid publication of accepted articles

- Access all the published articles

- Re-use any of the published material for personal use and teaching without further permission

For information on Institutional Fellowships contact consortiasales@bmjgroup.com

Visit casereports.bmj.com for more articles like this and to become a Fellow 